\title{
Edge effects without habitat fragmentation? Small mammals and a railway in the Atlantic Forest of southern Brazil
}

\author{
Ricardo A. S. Cerboncini, James J. Roper and Fernando C. Passos
}

\begin{abstract}
Edge effects have been studied extensively in fragmented landscapes, often with conflicting findings. Edge effects may also be important in other situations, such as linear clearings (e.g. along roads, power lines or train tracks). We tested for responses of small mammals to a narrow (c. $10 \mathrm{~m})$ linear clearing created by a railway in the largest area of Atlantic Forest in southern Brazil. Only two environmental variables, light intensity and train noise, were greatest at the edge and decreased with distance from the edge. Temperature differed (greater extremes and more variable) only at the edge itself. The few small mammal species that were only rarely captured at the edge resulted in an apparent edge-effect with respect to species richness. The abundance of small mammals, however, was independent of distance from the railway. There was no correlation between resource availability at the tracks and abundance of small mammals. Edge effects were minimal, which suggests that narrow railways (in contrast with roads) in unfragmented landscapes probably do not have a significant impact (if any) on wildlife, as found elsewhere and especially in tropical forests. The use of railways instead of roads is a potential strategy to minimize the effects of traversing important habitats for commercial reasons.
\end{abstract}

Keywords Atlantic Forest, Brazil, Didelphimorphia, fragmentation, linear clearing, microclimate, right of way, Rodentia

\section{Introduction}

T dge effects threaten biodiversity in many landscapes fragmented as a result of human activities (Harper

RicARdo A. S. CERbonCini ${ }^{*}$ (Corresponding author), JAMES J. Roper $\dagger$ and Fernando C. Passos* Programa de Pós-Graduação em Ecologia e Conservação, Setor de Ciências Biológicas, Universidade Federal do Paraná, Campus Centro Politécnico, 81531-970 Curitiba, Paraná, Brazil

E-mail ricardocerboncini@gmail.com

*Also at: Laboratório de Biodiversidade, Conservação e Ecologia de Animais Silvestres, Departamento de Zoologia, Setor de Ciências Biológicas, Universidade Federal do Paraná, Curitiba, Paraná, Brazil

$\dagger$ †lso at: Programa de Pós-graduação em Ecologia de Ecossistemas, Universidade de Vila Velha, Vila Velha, Espírito Santo, Brazil

Received 3 July 2014. Revision requested 29 August 2014.

Accepted 11 November 2014. First published online 11 February 2015. et al., 2005). Edges between different habitats were once considered beneficial for biodiversity (Leopold, 1933; Lay, 1938) but as studies focused on anthropogenic edges (Chasko \& Gates, 1982; Harris, 1988) their detrimental effects became apparent. Edges are abrupt transitions between habitats or ecosystems (Yahner, 1988; Ries et al., 2004) and their effects include any changes that occur as a result of that transition (Murcia, 1995). Abrupt transitions in vegetation at edges are usually associated with similarly abrupt changes in climate, with consequent impacts on plants and animals (Chasko \& Gates, 1982; Sork, 1983; Palik \& Murphy, 1990; Matlack, 1994; Oliveira et al., 2004) as a result of changing resource distribution (Mills et al., 1991; Berg \& Pärt, 1994; Ries \& Sisk, 2004) and biotic interactions (Berg \& Pärt, 1994; Fagan et al., 1999).

Diversity often increases near edges (especially in forest fragments) as a consequence of invasion by organisms from areas adjacent to the edge, both the forest interior and the newly created open area causing the edge (Yahner, 1988; Laurance, 1994; Gascon et al., 1999; Pardini, 2004). Conditions near edges are often similar to those of disturbed habitats (Chen et al., 1993; Cadenasso et al., 1997) and may therefore favour invasion by species typical of disturbances (Laurance, 1994; Pardini, 2004). Unique resources may be available near edges (Mills et al., 1991; Berg \& Pärt, 1994; Ries \& Sisk, 2004), also favouring invasion by species that prefer those resources.

Edge effects are well known in the context of habitat loss and fragmentation (Yahner, 1988; Murcia, 1995; Ries et al., 2004). However, linear clearings for rights of way (e.g. power lines, roads, railways) also produce edges, often in otherwise well-preserved landscapes (Laurance et al., 2009). Studies of the effects of roads and highways on wildlife have shown that these edges affect the diversity of understorey birds (Laurance, 2004) and small mammals (Goosem, 2000; Ruiz-Capillas et al., 2013). However, most studies have addressed these effects where edges are extensive and obvious. More subtle settings, such as smaller roads and rights of way, remain understudied and may have unexpected effects as a result of inputs of new resources that may, in turn, increase diversity (Carthew et al., 2013). For example, agricultural products may fall from trains while in transit, introducing plants or providing food for animals.

Anthropogenic edges in tropical forests are of particular concern because of the contrast between the more constant 
forest interior and the variable temperatures and greater extremes of the adjacent open areas, which may be agricultural, urban or rights of way for road, rail or power lines (Matlack, 1993; Pohlman et al., 2007; Laurance et al., 2009). As natural areas become increasingly fragmented, understanding the effects of fragmentation and edges is important for conservation. An estimated $73 \%$ of the Atlantic Forest is $<250 \mathrm{~m}$ from an edge (Ribeiro et al., 2009). In the future, these kinds of edges may be pervasive, and understanding their impact on wildlife will be important for appropriate management of biodiversity coexisting with small-scale edges.

Here we measured the response of small mammals to a railway in an otherwise well-preserved natural landscape. This setting is useful because it minimizes the effects of overdispersion of animals from an anthropogenic matrix (i.e. farms, rural and urban areas). We tested three hypotheses: the railway creates an environmental gradient in the forest (i.e. an edge effect exists), this edge has consequences for the small mammals inhabiting the forest, and the new resources introduced by trains hauling agricultural produce (usually soy and other grains) favour small mammals near the edge. By elucidating the impact of this edge within a well-preserved forest we hope to separate edge effects from the larger scale of the surrounding matrix.

\section{Study site}

We studied edge effects in Marumbi State Park (Parque Estadual Pico do Marumbi). The Park is in the central portion of the Coastal Mountain Range (Serra do Mar) in the state of Paraná, southern Brazil, and lies within the largest remnant of Atlantic Forest (Ribeiro et al., 2009; Fig. 1). The climate is humid year-round and without a marked dry season (mean annual rainfall c. 2,000 $\mathrm{mm}$ and mean annual temperature c. $20^{\circ} \mathrm{C}$; Vanhoni \& Mendonça, 2008). The study area is at 350-450 m altitude; vegetation is evergreen (Veloso et al., 1991), with emergent trees $>30 \mathrm{~m}$ tall and canopy at 20-25 $\mathrm{m}$. The most common plant families are Bromeliaceae, Myrtaceae, Rubiaceae, Melastomataceae and Fabaceae (Silva, 1989; Kaehler et al., 2005). The Paranaguá-Curitiba railway, established in 1885, passes through the Atlantic Forest of the Serra do Mar and connects the state capital, Curitiba, with the port of Paranaguá (110 km). It is used for commercial transportation of several products, such as grains (mainly soy, wheat and corn), fuel and paper, and also for tourism. In the study area the right of way is c. $10 \mathrm{~m}$ wide.

\section{Methods}

\section{Capture of small mammals}

We established four groups of transects parallel to the railway, with groups separated by $\geq 50 \mathrm{~m}$ along the railway.
Each group comprised four transects, one of which was at the edge ( $\mathrm{o} \mathrm{m}$ ), with $\mathrm{c}$. $50 \mathrm{~m}$ between each transect (thus the last was c.150 $\mathrm{m}$ from the edge). This sampling design was based on the fact that edge effects usually penetrate up to $100 \mathrm{~m}$ in fragments of tropical forest (Kapos, 1989; Matlack, 1993; Stevens \& Husband, 1998; Laurance et al., 2002; Oliveira et al., 2004). Sampling points were established at $5 \mathrm{~m}$ intervals along the $45 \mathrm{~m}$ transects. Sampling (8 days, 7 nights) was carried out monthly during February-July 2011; storms prevented sampling in March.

One Sherman trap (H.B. Sherman Traps, Tallahasse, USA) was placed at each sampling point. We alternated six small $(231 \times 87 \times 76 \mathrm{~mm})$ and four large $(371 \times 120 \times 103$ $\mathrm{mm})$ traps on and above the ground (1.5-2 m) on each transect. Captured animals were handled without anaesthesia, and marked with a numbered ear tag. All individuals were measured (head-and-body length) and weighed. Voucher specimens collected (licenses Instituto Ambiental do Paraná ${ }^{\circ}{ }^{2} 25 / 10$ and Instituto Chico Mendes de Conservação da Biodiversidade $\mathrm{n}^{\circ}$ 26769-1) are in the mammal collection of the Department of Zoology, Federal University of Paraná. Field procedures followed guidelines of the American Society of Mammalogists (Sikes et al., 2011). Information on the species of small mammals captured is in Cerboncini et al. (2014).

\section{Microclimate and environmental conditions}

We measured air temperature $\left({ }^{\circ} \mathrm{C}\right)$, relative humidity (\%, thermo-hygrometer, Instrutemp ITHT-2210), light intensity (lux, Instrutemp ITLD-26o) and ambient noise (dB, Instrutemp ITDEC-400o) at five randomly chosen points on all transects once during each sampling period. Noise was measured on each transect when a train passed by, which occurred at 1-3 hour intervals, day and night. The mean of each variable (except noise from trains) on each transect during each sampling period was used in analyses.

An additional $150 \mathrm{~m}$ transect perpendicular to the railway was used to measure a temperature gradient. For a fine-scale assessment of the microclimate, air temperature was measured along this transect using 16 Thermochron data loggers (Maxim Integrated, San Jose, USA). Data loggers were placed at $5 \mathrm{~m}$ intervals for the first $25 \mathrm{~m}$ from the edge, and subsequently at $10 \mathrm{~m}$ intervals to $75 \mathrm{~m}$ and then $15 \mathrm{~m}$ intervals to $150 \mathrm{~m}$. All data loggers recorded temperature simultaneously every hour for 71 hours during each sampling period. Based on natural temperature divisions, we categorized the sampling periods as warm (February and April), mild (May and July), and cold (June), to compare how temperature varied with distance from the edge, controlling for seasonality. 


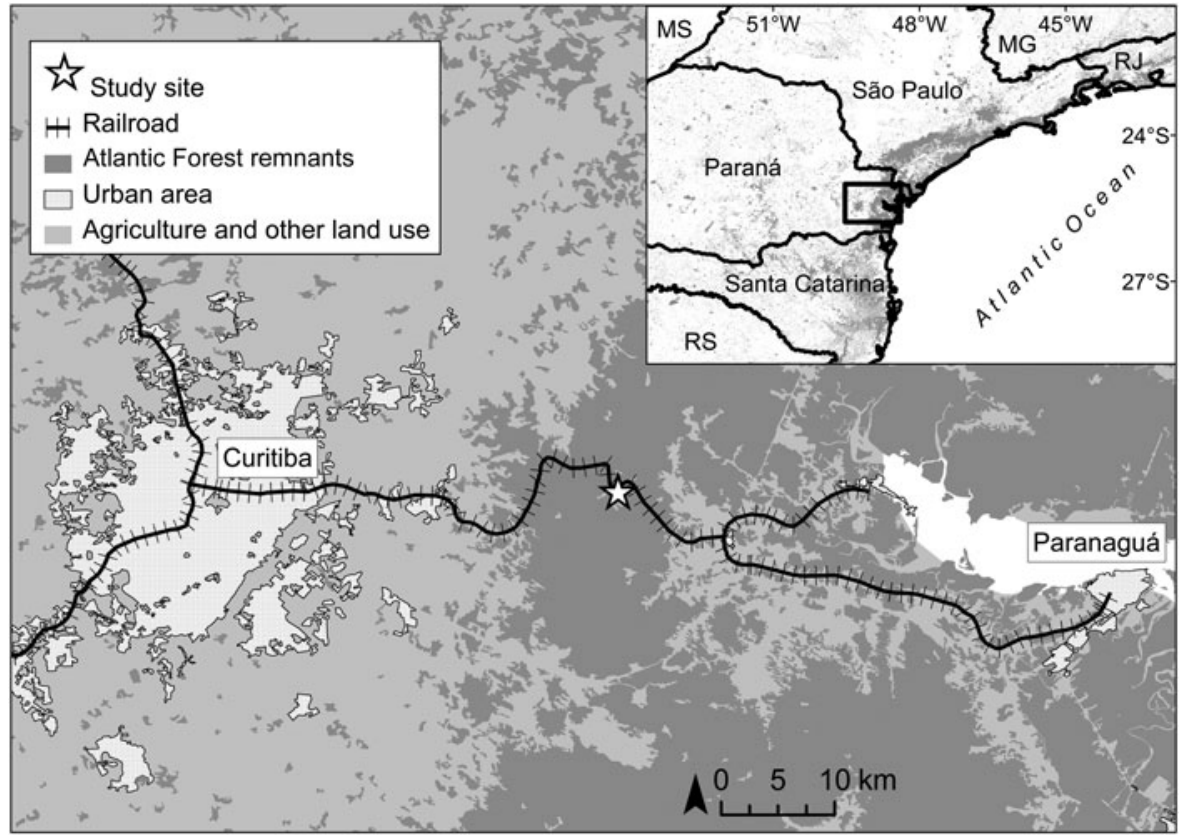

FIg. 1 The study site, where the Paranaguá-Curitiba railway passes through Marumbi State Park, in the Atlantic Forest of southern Brazil. The rectangle on the inset shows the location of the main map in Paraná state. Data on distribution of Atlantic forest patches are from SOS Mata Atlântica \& INPE (2011).

\section{Resources and edges}

We estimated resource availability at the railway tracks by collecting grains that had fallen from trains. We used seven seed-collectors $(70 \times 70 \mathrm{~cm})$ set in place on the first day of each sampling period, at $5 \mathrm{~m}$ intervals on both sides of the track (three on one side, four on the other). After 6 days we counted the number of grains collected as our relative estimate of grain availability. We focused on comparing sampling periods rather than estimating grain abundance on the railway.

\section{Data analysis}

We tested for correlations between total number of captures, abundance and number of species of small mammals, and distance from the edge. We also tested for relationships between distance from the edge and environmental variables, using linear regression analysis. Species abundance estimates were categorized according to distance from the edge (for the same sampling effort): $<10 \mathrm{~m}, 30-80 \mathrm{~m}, 81-120 \mathrm{~m}$, and $>120 \mathrm{~m}$. We calculated the Jaccard dissimilarity index between all sampling transects and tested if species composition depended on these edge distance categories, using ANOSIM (analysis of similarity) with 999 permutations.

To estimate body condition we used the residuals of a linear regression of body weight against length (SchulteHostedde et al., 2005). For species with $>10$ individuals captured on more than three transects within an interval of at least $100 \mathrm{~m}$ from the edge we tested for a relationship between condition, sex and distance from edge, using analysis of covariance. To avoid pseudoreplication we included only the first capture of any individual in the analysis.
We tested for a correlation between small mammal abundance near the edge (o $\mathrm{m}$ ) and number of grains collected, firstly using overall abundance of all species, and secondly focusing on granivorous species, following the dietary classification of Paglia et al. (2012). All statistical analyses were carried out with $R$ v. 3.o.2 (R Development Core Team, 2013); vegan (Oksanen et al., 2013) was used for ANOSIM. For statistical significance we assumed a $5 \%$ error rate.

\section{Results}

Edge and climate Air temperature $\left(\mathrm{F}_{1,78}=0.005, \mathrm{P}=0.94\right)$, relative humidity $\left(\mathrm{F}_{1,78}=0.59, \mathrm{P}=0.44\right)$ and environmental noise intensity $\left(\mathrm{F}_{1,78}=0.32, \mathrm{P}=0.58\right)$ were independent of distance from the edge. Light intensity $\left(\mathrm{F}_{1,78}=39.84\right.$, $\left.\mathrm{r}^{2}=0.33, \mathrm{P}<0.001\right)$ and train noise intensity $\left(\mathrm{F}_{1,80}=190.5\right.$, $\left.\mathrm{r}^{2}=0.7, \mathrm{P}<0.001\right)$ decreased with increasing distance from the edge (Fig. 2). There was no temperature gradient beginning at the edge during any season; only at the edge itself was temperature different from all other points. In general, higher maximum temperatures (but similar minimum temperatures) and thus greater variability were found at the edge (Fig. 3).

Small mammals We captured 12 small mammal species, four of which are granivorous (Table 1). Total capture $(\mathrm{S}=887.3, \mathrm{P}=0.25$, transect median $=22.5)$ and abundance $(\mathrm{S}=907.7, \mathrm{P}=0.2$, transect median $=13)$ were independent of distance from the edge, whereas the number of species captured declined towards the forest interior $(S=1049$, $\mathrm{r}_{\mathrm{s}}=-0.54, \mathrm{P}=0.03$, median for transects $<10 \mathrm{~m}$ from the edge $=7,30-70 \mathrm{~m}$ from the edge $=5$, and $>70 \mathrm{~m}$ from the 


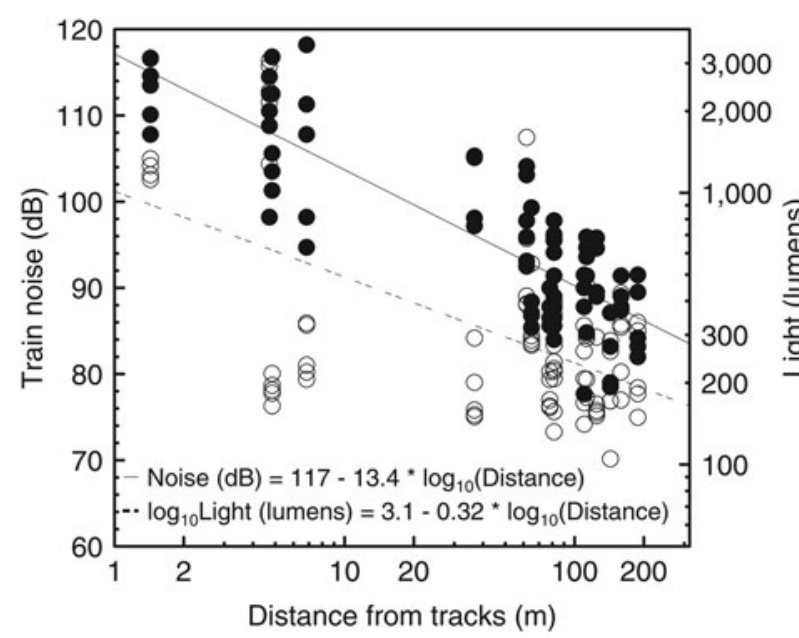

FIg. 2 The relationship of distance from the Paranaguá-Curitiba railway to light intensity (unfilled circles) and train noise (filled circles) in the Atlantic Forest in southern Brazil (Fig. 1). Axes are $\log _{10}$ scaled.

edge $=3$; Fig. 4). The most common species were approximately equally abundant at various distances from the edge, whereas the most uncommon species were captured only near the edge (Fig. 5). Species composition was similar at all distances from the edge (ANOSIM, $\mathrm{R}=0.09, \mathrm{P}=0.18)$. Body condition of all animals was independent of sex, and therefore sex was not included in the analysis of body condition and distance from edge. Body condition was independent of distance from the edge in all species $(\mathrm{P}>0.1)$.

Railway resources Soy ( $85 \%$ of all grains), corn (10\%) and wheat $(5 \%)$ that fell from passing trains were collected in our seed traps. The number of grains collected varied from o in February to 33 in May (13 in April, 7 in June and 12 in July). Grain was available near the tracks during every period, and the number of grains collected seemed to represent true availability (few grains were seen on the tracks during February, whereas large numbers were seen in May). The number of individuals of all mammal species captured at the edge was always independent of the number of grains collected (all species: $S=872.7$, $\mathrm{n}=20, \quad \mathrm{P}=0.14 ;$ granivorous species only: $\mathrm{S}=998.4$, $\mathrm{n}=20, \mathrm{P}=0.28$ ).

\section{Discussion}

\section{Microclimate and edge}

Despite the clear and abrupt transition between the open space and the forest, the edge had no apparent influence on microclimate. There was a marked gradient in both light and noise, both of which diminished with distance

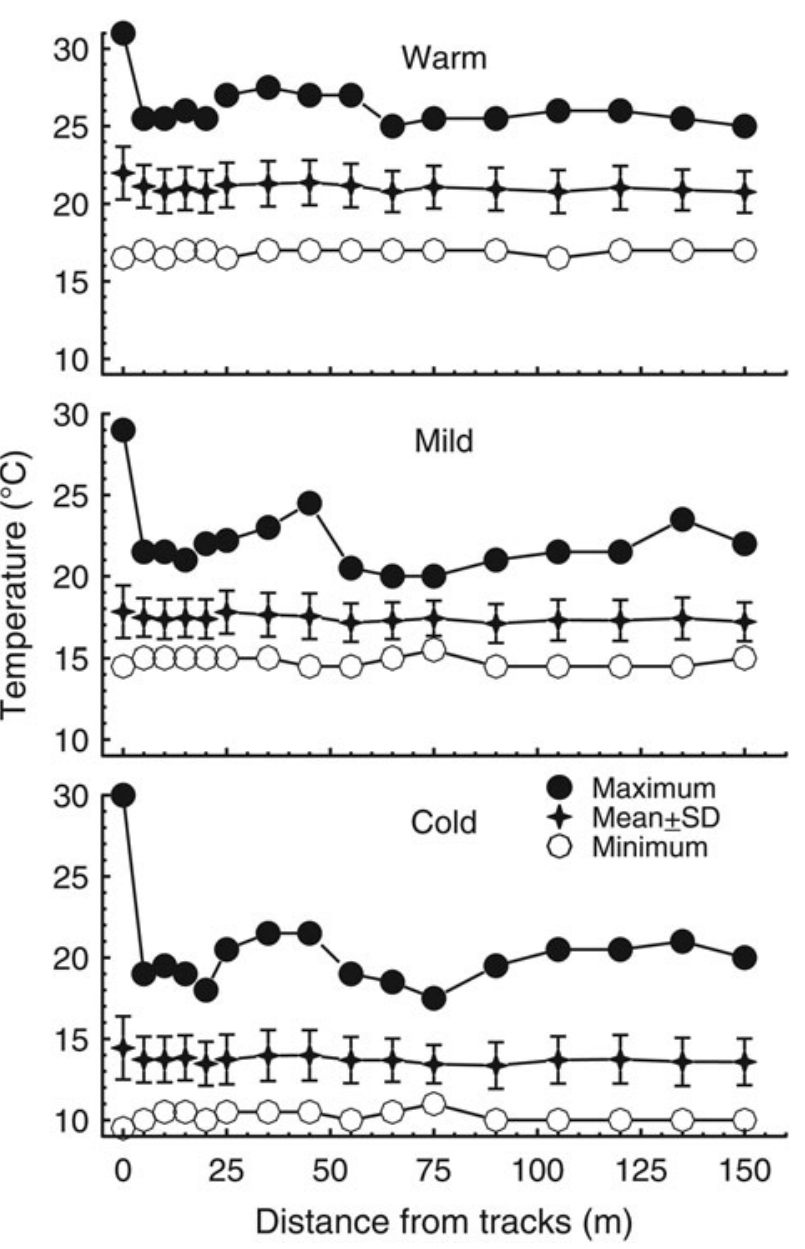

FIG. 3 Variation in temperature with distance from the Paranaguá-Curitiba railway towards the interior of the Atlantic Forest in southern Brazil (Fig. 1) during warm (February and April), mild (May and July) and cold (June) seasons.

from the train tracks, yet there was only a marked variation in temperature at the edge itself. In the tropics and elsewhere changes in microclimate can be detected up to $50 \mathrm{~m}$ from the edge (Kapos, 1989; Matlack, 1993; Stevens \& Husband, 1998). However, microclimate responses to edges are strongest when small forest fragments are bordered by open areas (Didham \& Lawton, 1999). The magnitude of microclimatic gradients as a result of edges usually depends on the size of the clearing (Pohlman et al., 2007). Thus the absence of a microclimate gradient may be attributable to the clearing along the Paranaguá-Curitiba railway being narrow and linear (Laurance et al., 2009) in a well-preserved, forested landscape.

Edge effects on light intensity (Kapos, 1989; Matlack, 1993; Young \& Mitchell, 1994; Cadenasso et al., 1997) can influence plant survival, reproduction and seed germination (Boardman, 1977). This interaction often favours pioneer or invasive plants (Bazzaz, 1979; Kapos, 1989; Brothers \& Spingarn, 1992) and can cause an increase in plant density (Willson \& Crome, 1989; Camargo \& Kapos, 1995) and 
TABLE 1 The 12 small mammal species captured along the railway at Marumbi State Park, Paraná, Brazil (Fig. 1), with number of captures, and type of diet.

\begin{tabular}{|c|c|c|}
\hline Taxon & No. of captures & Diet $^{*}$ \\
\hline \multicolumn{3}{|l|}{ Didelphimorphia } \\
\hline Big-eared opossum Didelphis aurita & 7 & Frugivorous/Omnivorous \\
\hline South-eastern four-eyed opossum Philander frenatus & 18 & Insectivorous/Omnivorous \\
\hline Tate's woolly mouse opossum Marmosa paraguayana & 54 & Insectivorous/Omnivorous \\
\hline Brazilian gracile opossum Gracilinanus microtarsus & 1 & Insectivorous/Omnivorous \\
\hline \multicolumn{3}{|l|}{ Rodentia } \\
\hline \multicolumn{3}{|l|}{ Cricetidae } \\
\hline Lesser Wilfred's mouse Juliomys pictipes & 28 & Frugivorous/Seed predator \\
\hline Montane grass mouse Akodon montensis & 11 & Insectivorous/Omnivorous \\
\hline Hocicudo Oxymycterus sp. & 3 & Insectivorous/Omnivorous \\
\hline Russet rice rat Euryoryzomys russatus & 179 & Frugivorous/Granivorous \\
\hline South American water rat Nectomys squamipes & 3 & Frugivorous/Omnivorous \\
\hline Rat-headed rice rat Sooretamys angouya & 24 & Frugivorous/Granivorous \\
\hline Black-footed pygmy rice rat Oligoryzomys nigripes & 11 & Frugivorous/Granivorous \\
\hline \multicolumn{3}{|l|}{ Echimyidae } \\
\hline Ihering's spiny rat Trinomys iheringi & 1 & Frugivorous/Granivorous \\
\hline
\end{tabular}

${ }^{*}$ Diet classification following Paglia et al. (2012)

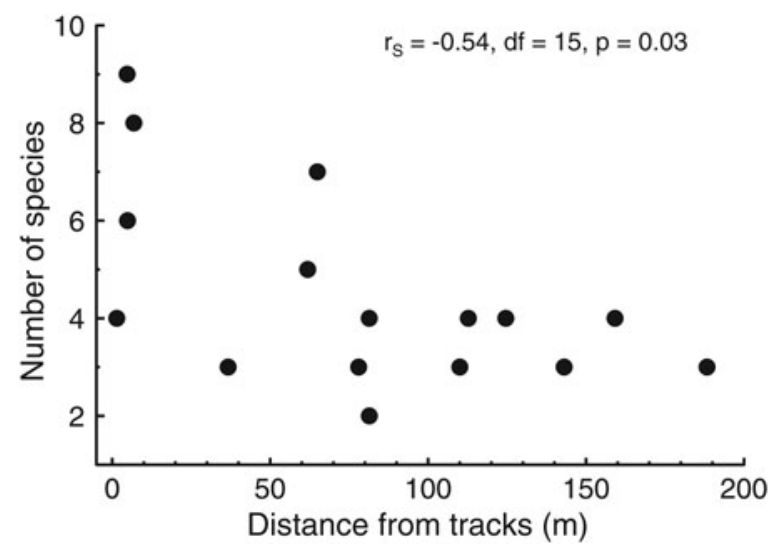

FIG. 4 The variation in number of species of small mammals captured with distance from the Paranaguá-Curitiba railway in the Atlantic Forest in southern Brazil (Fig. 1). The higher number of species near the edge is partly attributable to the capture of one or few individuals of some species (Fig. 5).

diversity (Harper et al., 2005). Here, however, if such edge conditions existed their influence on small mammals (through their influence on vegetation) was not measurable. Anthropogenic noise can be detrimental to wildlife for a variety of reasons, such as increased stress causing abnormal feeding and reproductive behaviours and other consequences that can influence fitness (Marler \& Sherman, 1983; Andersen et al., 1990; Awbrey \& Bowles, 1990). We suggest that noise along the railway track is sporadic and relatively rare compared to other edge situations, and probably causes little disturbance. The impact of noise near roads depends on noise intensity and the rate and duration of traffic, and thus there is a greater impact on wildlife near larger roads (Kaseloo, 2005). In Marumbi State Park trains usually pass every few hours and, although noise may be intensely loud (up to $120 \mathrm{~dB}$ ) near the railway, infrequent passage probably minimizes any effects on small mammals. It is also possible that small mammals derive a benefit from the noise because it may perturb potential predators. If so, this effect was not at a scale that was detectable in this study. Thus, the effect of noise from trains is apparently insignificant at current rates of train traffic in the Park.

\section{Small mammals did not respond to the edge}

We found no clear influence of edge effects on the group of mammals studied, which were typical of well-preserved Atlantic Forest (Cerboncini et al., 2014). Capture probability of the most common mammal in the study, the russet rice rat Euryoryzomys russatus, was independent of all edge characteristics. A few uncommon species were captured only near the edge (Fig. 5) but are not thought to be associated with edges or disturbances. Spiny rats Trinomys spp. are typical in well-conserved coastal Atlantic Forest (Vieira et al., 2009), and Ihering's spiny rat Trinomys iheringi was found in the Park at the limits of its distribution (Cerboncini et al., 2014). Similarly, the South American water rat Nectomys squamipes is often found in forest patches with riparian areas, regardless of the size or quality of the fragment (Pires et al., 2002; Viveiros de Castro \& Fernandez, 2004). The Brazilian gracile mouse opossum Gracilinanus microtarsus is a habitat generalist, as long as forest is available (Pardini et al., 2005), and therefore the fact that this species was captured only near the edge does not suggest an edge effect (i.e. changes in community near edges), given the small number of captures. Anthropogenic, permanent linear clearings such as train rights of way may 


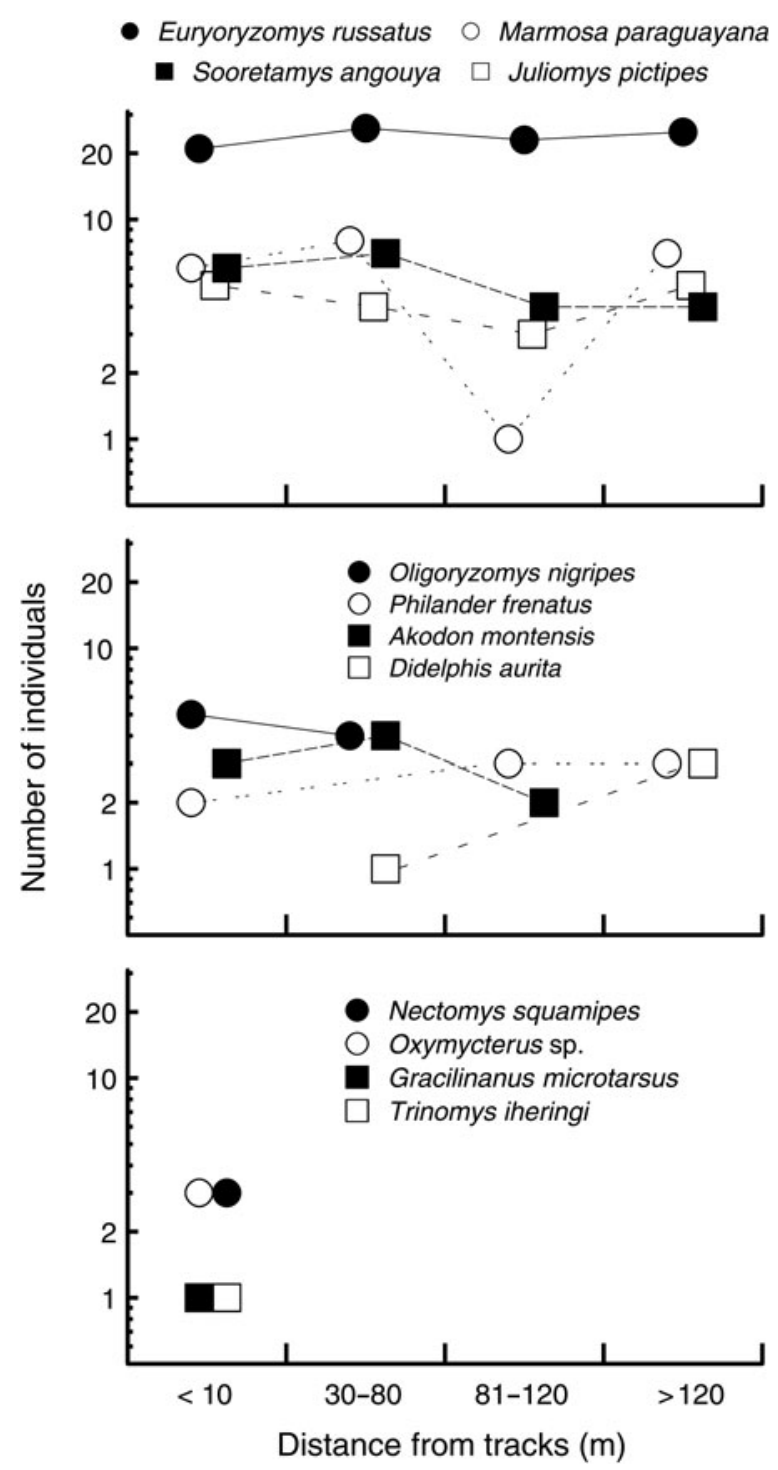

FIG. 5 Variation in abundance of small mammal species with distance from the Paranaguá-Curitiba railway in the Atlantic forest in southern Brazil (Fig. 1).

be unsuitable, and even dangerous, for wildlife but appear to have little effect in the nearby forest.

The lack of correlation between the body condition of small mammals and distance from the edge also suggest little or no edge effect. Body condition is important for survival and reproduction (Millar \& Hickling, 1990; Virgl \& Messier, 1992; Zuercher et al., 1999; Schulte-Hostedde et al., 2001), and in female mammals is often associated with reproductive success (Atkinson \& Ramsay, 1995; Dobson \& Michener, 1995; Wauters \& Dhondt, 1995). The absence of an effect suggests there is no stress associated with the edge or associated noises. In contrast, a study in the Caribbean found the body condition of female rodents declined near roads (Fuentes-Montemayor et al., 2009). Further study to determine which factors are detrimental to rodents near edges is necessary to compare the impacts of various types of edges.

\section{Railway resources}

Increased availability of resources may be one of the main reasons for increased diversity near edges (McCollin, 1998, Ries \& Sisk, 2004; Ries et al., 2004). Food is often superabundant as a result of grain falling from trains but abundance of this resource had no measurable impact on small mammals. Although the number of small mammal species captured was greater near the edge, this is probably not a typical edge effect but a consequence of minor changes in the forest near the edge.

\section{Rights of way and wildlife conservation}

In Brazil roads are used more often than railways for commercial transportation. However, railways appear to have less impact on wildlife than do roads and highways. The construction of roads is usually followed by uncontrolled immigration and logging, hunting, agriculture and land speculation, which are the main causes of the destruction of tropical forests (Young, 1994; Laurance et al., 2004; Fearnside, 2007). Increasing the use of railways for transport could be a useful conservation strategy, especially where it is necessary to transport agricultural or industrial products through important habitats.

Environmental edge effects in this landscape were minimal, with no measurable consequences for small mammals, except for infrequent encounters with some species only at the edge. It is important to note that the ParanaguáCuritiba railway is $>100$ years old and some species may have had sufficient time to adapt to the different environmental conditions created by the right of way. Whether newly constructed railways produce more intense edge effects remains to be investigated.

\section{Acknowledgements}

We thank the following for their invaluable help in the field: Talita V. Braga, Marcelo B. G. Rubio, Itiberê P. Bernardi, Jennifer de S. B. Pereira, Viviane Mottin, Bruna C. R. de Jesus, Luiz H. Varzinczak, Felipe L. S. Shibuya, Fernanda F. C. de Lima and Jaqueline P. Duarte. Our research was permitted by Instituto Ambiental do Paraná and the Park Manager Lothário H. Stoltz Jr, who also provided transportation and accommodation at the study site. Instituto Chico Mendes de Conservação da Natureza provided permits to capture and collect small mammals. Marcelo Passamani and Maurício O. Moura provided valuable suggestions for this article. A scholarship was granted to RASC by the Coordenação de Aperfeiçoamento de Pessoal de Nível 
Superior, and the Conselho Nacional de Desenvolvimento Científico e Tecnológico provided support for FCP (303757/2012-4) and JJR (306963/2012-4).

\section{References}

Andersen, D.E., Rongstad, O.J. \& Mytton, W.R. (1990) Home-range changes in raptors exposed to increased human activity levels in southeastern Colorado. Wildlife Society Bulletin, 18 , 134-142.

Atkinson, S.N. \& Ramsay, M.A. (1995) The effects of prolonged fasting on the body composition and reproductive success of female polar bears (Ursus maritimus). Functional Ecology, 9, 559-567.

Awbrey, F.T. \& Bowles, A.E. (1990) Effects of Aircraft Noise and Sonic Booms on Raptors: A Preliminary Model and a Synthesis of the Literature on Disturbance. Noise and Sonic Boom Impact Technology, Brooks Airport Base, San Antonio, USA.

BAzZAZ, F.A. (1979) The physiological ecology of plant succession. Annual Review of Ecology and Systematics, 10, 351-371.

BERG, A. \& P ̈̈RT, T. (1994) Abundance of breeding farmland birds on arable and set-aside fields at forest edges. Ecography, 17, 147-152.

BoARDMAN, N.K. (1977) Comparative photosynthesis of sun and shade plants. Annual Review of Plant Physiology, 28, 355-377.

Brothers, T.S. \& SPINGARN, A. (1992) Forest fragmentation and alien plant invasion of central Indiana old-growth forests. Conservation Biology, 6, 91-100.

Cadenasso, M.L., Traynor, M.M. \& Pickett, S.T.A. (1997) Functional location of forest edges: gradients of multiple physical factors. Canadian Journal of Forest Research, 27, 774-782.

Camargo, J.L.C. \& Kapos, V. (1995) Complex edge effects on soil moisture and microclimate in central Amazonian forest. Journal of Tropical Ecology, 11, 205-221.

Carthew, S.M., Jones, K.M.W. \& Lawes, M. (2013) Responses of small vertebrates to linear clearings in a South Australian woodland. Ecological Research, 28, 1003-1010.

Cerboncini, R.A.S., Rubio, M.B.G., Bernardi, I.P., Braga, T.V., Roper, J.J. \& Passos, F.C. (2014) Small mammal community structure and vertical space use preferences in nonfragmented Atlantic Forest. Mammalia, 78, 429-436.

Chasko, G.G. \& Gates, J.E. (1982) Avian habitat suitability along a transmission-line corridor in an oak-hickory forest region. Wildlife Monographs, 82, 3-41.

Chen, J., Franklin, J.F. \& Spies, T.A. (1993) Contrasting microclimates among clearcut, edge, and interior of old-growth Douglas-fir forest. Agricultural and Forest Meteorology, 63, 219-237.

Didham, R.K. \& Lawton, J.H. (1999) Edge structure determines the magnitude of changes in microclimate and vegetation structure in tropical forest fragments. Biotropica, 31, 17-30.

Dobson, F.S. \& Michener, G.R. (1995) Maternal traits and reproduction in Richardson's ground squirrels. Ecology, 76, 851-862.

FaGan, W.F., Cantrell, R.S. \& Cosner, C. (1999) How habitat edges change species interactions. The American Naturalist, 153, 165-182.

Fearnside, P.M. (2007) Brazil's Cuiabá-Santarém (BR-163) highway: the environmental cost of paving a soybean corridor through the Amazon. Environmental Management, 39, 601-614.

Fuentes-Montemayor, E., Cuarón, A.D., Vázquez-Domínguez, E., Benítez-Malvido, J., Valenzuela-Galván, D. \& Andresen, E. (2009) Living on the edge: roads and edge effects on small mammal populations. Journal of Animal Ecology, 78, 857-865.

Gascon, C., Lovejoy, T.E., Bierregaard, R.O., Malcom, J.R., Stouffer, P.C., Vasconcelos, H.L. et al. (1999) Matrix habitat and species richness in tropical forest remnants. Biological Conservation, 91, 223-229.

Goosem, M. (200o) Effects of tropical rainforest roads on small mammals: edge changes in community composition. Wildlife Research, 27, 151-163.

Harper, K.A., MacDonald, S.E., Burton, P.J., Chen, J., Brosofske, K.D., SAunders, S.C. et al. (2005) Edge influence on forest structure and composition in fragmented landscapes. Conservation Biology, 19, 768-782.

Harris, L.D. (1988) Edge effects and conservation of biotic diversity. Conservation Biology, 2, 330-332.

Kaehler, M., Varassin, I.G. \& Goldenberg, R. (2005) Polinização em uma comunidade de bromélias em Floresta Atlântica alto-montana no estado do Paraná, Brasil. Revista Brasileira de Botânica, 28, 219-228.

KAPOS, V. (1989) Effects of isolation on the water status of forest patches in the Brazilian Amazon. Journal of Tropical Ecology, 5, 173-185.

KASELOO, P.A. (2005) Synthesis of noise effects on wildlife populations. In Proceedings of the 2005 International Conference on Ecology and Transportation (eds C.L. Irwin, P. Garrett \& K. P. McDermott), pp. 33-35. Center for Transportation and the Environment, North Carolina State University, Raleigh, USA.

LAURAnCE, S.G.W. (2004) Responses of understory rain forest birds to road edges in central Amazonia. Ecological Applications, 14, 1344-1357.

LAURANCE, W.F. (1994) Rainforest fragmentation and the structure of small mammal communities in tropical Queensland. Biological Conservation, 69, 23-32.

Laurance, W.F., Albernaz, A.K.M., Fearnside, P.M., Vasconcelos, H.L. \& Ferreira, L.V. (2004) Deforestation in Amazonia. Science, 304, 1109-1111.

Laurance, W.F., Goosem, M. \& Laurance, S.G.W. (2009) Impacts of roads and linear clearings on tropical forests. Trends in Ecology and Evolution, 24, 659-669.

Laurance, W.F., Lovejoy, T.E., Vasconcelos, H.L., Bruna, E.M., Didham, R.K., Stouffer, P.C. et al. (2002) Ecosystem decay of Amazonian forest fragments: a 22-year investigation. Conservation Biology, 16, 605-618.

LAY, D.W. (1938) How valuable are woodland clearings to birdlife? The Wilson Bulletin, 50, 254-256.

Leopold, A. (1933) Game Management. University of Wisconsin Press, Madison, USA.

Marler, P. \& Sherman, V. (1983) Song structure without auditory feedback: emendations of the auditory template hypothesis. Journal of Neuroscience, 3, 517-531.

MATLACK, G.R. (1993) Microenvironment variation within and among forest edge sites in the eastern United States. Biological Conservation, 66, 185-194.

MATLACK, G.R. (1994) Vegetation dynamics of the forest edge-trends in space and successional time. Journal of Ecology, 82, 113-123.

McCollin, D. (1998) Forest edges and habitat selection in birds: a functional approach. Ecography, 21, 247-260.

Millar, J.S. \& Hickling, G.J. (1990) Fasting endurance and the evolution of mammalian body size. Functional Ecology, 4, 5-12.

Mills, G.S., Dunning, JR, J.B. \& Bates, J.M. (1991) The relationship between breeding bird density and vegetation volume. The Wilson Bulletin, 103, 468-479.

Murcia, C. (1995) Edge effects in fragmented forests: implications for conservation. Trends in Ecology and Evolution, 10, 58-62.

Oksanen, J., Guillaume Blanchet, F., Kindt, R., Legendre, P., Minchin, P.R., O’Hara, R.B. et al. (2013). vegan: Community Ecology Package. R package version 2.0-8. Http://CRAN.R-project. org/package $=$ vegan [accessed 18 November 2014]. 
Oliveira, M.A., Grillo, A.S. \& Tabarelli, M. (2004) Forest edge in the Brazilian Atlantic forest: drastic changes in tree species assemblages. Oryx, 38, 389-394.

Paglia, A.P., Fonseca, G.B., Rylands, A.B., Herrmann, G., Aguiar, L.M.S., Chiarello, A.G. et al. (2012) Annotated Checklist of Brazilian Mammals. Occasional Papers in Conservation Biology, No. 6. Conservation International, Arlington, USA.

PALIK, B.J. \& MurPhy, P.G. (1990) Disturbance versus edge effects in sugar-maple/beech forest fragments. Forest Ecology and Management, 32, 187-202.

PARDINI, R. (2004) Effects of forest fragmentation on small mammals in an Atlantic Forest landscape. Biodiversity and Conservation, 13, $2567-2586$.

Pardini, R., De Souza, S.M., Braga-Neto, R. \& Metzger, J.P. (2005) The role of forest structure, fragment size and corridors in maintaining small mammal abundance and diversity in an Atlantic forest landscape. Biological Conservation, 124, 253-266.

Pires, A.S., Lira, P.K., Fernandez, F.A.S., Schittini, G.M. \& Oliveira, L.C. (2002) Frequency of movements of small mammals among Atlantic coastal forest fragments in Brazil. Biological Conservation, 108, 229-237.

Pohlman, C.L., Turton, S.M. \& Goosem, M. (2007) Edge effects of linear canopy openings on tropical rain forest understory microclimate. Biotropica, 39, 62-71.

R Development Core Team (2013) R: A Language and Environment for Statistical Computing. R Foundation for Statistical Computing, Vienna. Austria. Http://www.R-project.org/ [accessed 18 November 2014].

Ribeiro, M.C., Metzger, J.P., Martensen, A.C., Ponzoni, F.J. \& Hirota, M.M. (2009) The Brazilian Atlantic Forest: How much is left, and how is the remaining forest distributed? Implications for conservation. Biological Conservation, 142, 1141-1153.

Ries, L., Fletcher, JR, R.J., Battin, J. \& Sisk, T.D. (2004) Ecological responses to habitat edges: mechanisms, models, and variability explained. Annual Review of Ecology, Evolution, and Systematics, 35, 491-522.

RIES, L. \& SisK, T.D. (2004) A predictive model of edge effects. Ecology, 85, 2917-2926.

Ruiz-Capillas, P., Mata, C. \& Malo, J.E. (2013) Road verges are refuges for small mammal populations in extensively managed Mediterranean landscapes. Biological Conservation, 158, 223-229.

Schulte-Hostedde, A.I., Millar, J.S. \& Hickling, G.J. (2001) Evaluating body condition in small mammals. Canadian Journal of Zoology, 79, 1021-1029.

Schulte-Hostedde, A.I., Zinner, B., Millar, J.S. \& Hickling, G.J. (2005) Restitution of mass-size residuals: validating body condition indices. Ecology, 86, 155-163.

Sikes, R.S., Gannon, W.L. \& The Animal Care and Use Committee of the American Society of Mammalogists (2011) Guidelines of the American Society of Mammalogists for the use of wild mammals in research. Journal of Mammalogy, 92, 235-253.

Silva, F.C. (1989) Composição florística e estrutura fitossociológica da floresta tropical ombrófila da encosta Atlântica no município de Morretes (Paraná). Boletim de Pesquisa Florestal, 18/19, 31-49.
Sork, V.L. (1983) Distribution of pignut hickory (Carya glabra) along a forest to edge transect, and factors affecting seedling recruitment. Bulletin of the Torrey Botanical Club, 110, 494-506.

SOS Mata Atlântica \& INPE (Instituto Nacional de Pesquisas Espaciais) (2011) Atlas dos remanescentes florestais da Mata Atlântica, período de 2008 a 2010. Http://mapas.sosma.org.br [accessed 18 November 2014].

Stevens, S.M. \& Husband, T.P. (1998) The influence of edge on small mammals: evidence from Brazilian Atlantic forest fragments. Biological Conservation, 85, 1-8.

VAnhoni, F. \& Mendonça, F. (2008) O clima do litoral do estado do Paraná. Revista Brasileira de Climatologia, 3/4, 49-63.

Veloso, H.P., Rangel-Filho, A.L.R. \& Lima, J.C.A. (1991) Classificação da vegetação brasileira, adaptada a um sistema universal. IBGE, Rio de Janeiro, Brazil.

Vieira, M.V., Olifiers, N., Delciellos, A.C., Antunes, V.Z., Bernardo, L.R., Grelle, C.E.V. \& Cerqueira, R. (2009) Land use vs fragment size and isolation as determinants of small mammal composition and richness in Atlantic Forest remnants. Biological Conservation, 142, 1191-1200.

Virgl, J.A. \& Messier, F. (1992) Seasonal variation in body composition and morphology of adult muskrats in central Saskatchewan, Canada. Journal of Zoology, 228, 461-477.

Viveiros de Castro, E.B. \& Fernandez, F.A.S. (2004) Determinants of differential extinction vulnerabilities of small mammals in Atlantic forest fragments in Brazil. Biological Conservation, 119, 73-80.

Wauters, L.A. \& DhONDT, A.A. (1995) Lifetime reproductive success and its correlates in female Eurasian red squirrels. Oikos, 72, 402-410.

Willson, M.F. \& Crome, F.H.J. (1989) Patterns of seed rain at the edge of a tropical Queensland rain forest. Journal of Tropical Ecology, 5, 301-308.

YAhneR, R.H. (1988) Changes in wildlife communities near edges. Conservation Biology, 2, 333-339.

Young, A. \& Mitchell, N. (1994) Microclimate and vegetation edge effects in a fragmented podocarp-broadleaf forest in New Zealand. Biological Conservation, 67, 63-72.

YounG, K.R. (1994) Roads and the environmental degradation of tropical montane forests. Conservation Biology, 8, 972-976.

Zuercher, G.L., Roby, D.D. \& Rexstad, E.A. (1999) Seasonal changes in body mass, composition, and organs of northern red-backed voles in interior Alaska. Journal of Mammalogy, 8o, 443-459.

\section{Biographical sketches}

Ricardo Cerboncini is interested in ecology, conservation and evolution of biodiversity. His research focuses on the ecology of rodents and marsupials in human-altered landscapes, and on the evolution of behavioural traits, especially breeding systems and parental care of birds. JA M ES ROPER is interested in a broad variety of ecological and evolutionary questions, especially those related to population dynamics. Most of his research includes analysis of reproductive success and survival of terrestrial vertebrates. FERNANDO PASsos works in wildlife biology and conservation. His research includes small and large mammals, and he has developed most of his studies based on the bats and primates of the Atlantic Forest. 